\title{
Experimental Translational Research Using siRNA to Target Vascular Genesis in Inhibition of Mammary Cancer Metastasis
}

\author{
Masa-Aki Shibata ${ }^{1 *}$, Eiko Shibata², Shigekazu Fujioka1 and Mariko Harada-Shiba² \\ ${ }^{1}$ Laboratory of Anatomy and Histopathology, Graduate School of Health Sciences, Osaka Health Science University, Japan \\ ${ }^{2}$ Department of Molecular Innovation in Lipidology, National Cerebral \& Cardiovascular Center Research Institute, Japan
}

According to the International Agency for Research on Cancer (IARC), an estimated $1,384,000$ patients world-wide were diagnosed with breast cancer in 2008 and 458,000 women died of the disease [1]. Breast cancer mortality is largely due to metastasis; this is the biggest issue in cancer therapy. To delay disease progression and prolong patient life, metastasis must be conquered.

Cancer cells spread through the body by different mechanisms, such as direct invasion of surrounding tissue, dispersion of cells via the blood vascular system (i.e., hematogenous metastasis), and/or dissemination by means of the lymphatic system (i.e., lymphatic metastasis). Lymph node metastasis is one of the most important adverse prognostic factors in breast carcinoma [2]. An adequate blood supply is required to sustain the uncontrolled cell proliferation characteristic of malignant tumors, and tumorigenesis and metastasis have both been associated with angiogenesis [3]. Thus, members of the vascular endothelial growth factor (VEGF) family, which promote the formation of new blood and lymphatic vessels in tumor tissues and enable the spread of tumor cells [4], have come under particular scrutiny. Within the VEGF family, VEGF-A is also known to exert a crucial role in tumor angiogenesis [3], while both VEGF-C and VEGF-D have been reported to induce lymphangiogenesis via activation of the VEGF receptor-3 (VEGFR3) expressed on lymphatic endothelial cells [5,6]. In animal models, VEGF-C and VEGF-D have also been shown to enhance lymphangiogenesis and associated lymphatic metastasis [7-13], while clinical studies have demonstrated overexpression of either VEGF-C or VEGF-D associated with lymph node metastasis and poor prognosis in breast cancer patients [14-17].

Within the past several years, RNA interference has become the most widely used technology for gene silencing. A popular therapeutic concept involves knockdown of target mRNA expression by gene silencing using vectors expressing short interfering RNA (siRNA). In order to suppress mammary cancer metastasis by vascular spread, siRNA was used in several studies performed in our laboratory. Using a particular murine mammary cancer cell line producing a metastatic spectrum similar to that seen in human breast cancers, we demonstrated inhibitory effects on lymph node metastasis by siRNA expression vectors targeting Vegf-c $[18,19]$ or Vegf- $a$ [20] using in vivo gene electrotransfer in an immunocompetent mouse mammary cancer model. However, Vegf- $d$ siRNA therapy did not prove effective in our mammary cancer model [19] (Note: analogous genes in the mouse are referenced in italics with the first letter only capitalized).

In clinical studies performed by Currie et al., [21] no association between VEGF-D and lymph node metastasis was found in human breast cancer [21], while another group of investigators linked high expression of VEGF-A and VEGF-C, but again not VEGF-D, with poor prognosis [22]. More recently, another clinical study demonstrated that only tumor-derived VEGF-C induced pre-metastatic sentinel node lymphangionenesis in primary breast cancer [23]. In addition, we recently reported that a new splicing variant, endogenous soluble vascular endothelial growth factor receptor-2 (esVegfr-2) inhibits
VEGF-C function [24] and metastasis in a mouse model of metastatic mammary cancer [20].

Even though gene therapy targeting vascular genesis using Vegf-c and Vegf- $a$ silencing was able to inhibit mammary cancer metastasis in our animal model, there are many issues to be addressed in a human application, including the method of gene introduction, delivery of a gene to a specific target organ, patient safety and so on. Recently, the molecule Akt is garnering attention as the key downstream effector of phosphatidylinositol-3-kinase (PI3K). Akt activation (phosphorylation) induces oncogenic signaling for such functions as vascular genesis, cell proliferation, cell growth, migration, anti-apoptosis, etc. A new avenue in cancer therapeutics is development of drugs that induce Akt dephosphorylation as another possible way to inhibit metastasis. In the trend towards primary and adjunctive use of natural products, we found $\alpha$-manogstin, an extract of the pericarp of the mangosteena fruit native to Southeast Asia-induces Akt dephosphorylation and inhibition of vascular genesis, and results in inhibition of metastasis in our mouse model of mammary cancer model $[25,26]$. These data support our conclusion that targeting vascular genesis (in particular, lymphangiogenesis) may have great clinical significance in the treatment of metastatic human breast cancer.

\section{References}

1. International Agency Research on Cancer (2008) Globocan.

2. Cody HS 3rd, Borgen PI, Tan LK (2004) Redefining prognosis in node-negative breast cancer: can sentinel lymph node biopsy raise the threshold for systemic adjuvant therapy? Ann Surg Oncol 11: 227S-30S.

3. Roy H, Bhardwaj S, Ylä-Herttuala S (2006) Biology of vascular endothelial growth factors. FEBS Lett 580: 2879-2887.

4. Achen MG, Stacker SA (2008) Molecular control of lymphatic metastasis. Ann N Y Acad Sci 1131: 225-234.

5. Joukov V, Pajusola K, Kaipainen A, Chilov D, Lahtinen I, et al. (1996) A nove vascular endothelial growth factor, VEGF-C, is a ligand for the FIt4 (VEGFR-3) and KDR (VEGFR-2) receptor tyrosine kinases. EMBO J 15: 290-298.

6. Achen MG, Jeltsch M, Kukk E, Mäkinen T, Vitali A, et al. (1998) Vascular endothelial growth factor D (VEGF-D) is a ligand for the tyrosine kinases VEGF receptor 2 (FIk1) and VEGF receptor 3 (Flt4). Proc Natl Acad Sci U S A 95: 548-553.

*Corresponding author: Masa-Aki Shibata, Laboratory of Anatomy and Histopathology, Graduate School of Health Sciences, Osaka Health Science University, 1-9-27 Temma, Kita-ku, Osaka 530-0043 Japan, Tel: +81-6-7506- 9046 Fax: +81-6-6352-5995; E-mail: masaaki.shibata@ohsu.ac.jp

Received November 11, 2013; Accepted November 11, 2013; Published November 13, 2013

Citation: Shibata MA, Shibata E, Fujioka S, Harada-Shiba M (2013) Experimenta Translational Research Using siRNA to Target Vascular Genesis in Inhibition of Mammary Cancer Metastasis. Altern Integ Med 2: e109. doi:10.4172/23275162.1000e109

Copyright: (c) 2013 Shibata MA, et al. This is an open-access article distributed under the terms of the Creative Commons Attribution License, which permits unrestricted use, distribution, and reproduction in any medium, provided the original author and source are credited. 
Citation: Shibata MA, Shibata E, Fujioka S, Harada-Shiba M (2013) Experimental Translational Research Using siRNA to Target Vascular Genesis in Inhibition of Mammary Cancer Metastasis. Altern Integ Med 2: e109. doi:10.4172/2327-5162.1000e109

7. Skobe M, Hawighorst T, Jackson DG, Prevo R, Janes L, et al. (2001) Induction of tumor lymphangiogenesis by VEGF-C promotes breast cancer metastasis. Nat Med 7: 192-198.

8. Mandriota SJ, Jussila L, Jeltsch M, Compagni A, Baetens D, et al. (2001) Vascular endothelial growth factor-C-mediated lymphangiogenesis promotes tumour metastasis. EMBO J 20: 672-682.

9. Karpanen T, Egeblad M, Karkkainen MJ, Kubo H, Ylä-Herttuala S, et al. (2001) Vascular endothelial growth factor $\mathrm{C}$ promotes tumor lymphangiogenesis and intralymphatic tumor growth. Cancer Res 61: 1786-1790.

10. Achen MG, Mann GB, Stacker SA (2006) Targeting lymphangiogenesis to prevent tumour metastasis. Br J Cancer 94: 1355-1360.

11. Stacker SA, Caesar C, Baldwin ME, Thornton GE, Williams RA, et al. (2001) VEGF-D promotes the metastatic spread of tumor cells via the lymphatics. Nat Med 7: 186-191.

12. Von Marschall Z, Scholz A, Stacker SA, Achen MG, Jackson DG, et al. (2005) Vascular endothelial growth factor-D induces lymphangiogenesis and lymphatic metastasis in models of ductal pancreatic cancer. Int J Oncol 27: 669-679.

13. Kopfstein L, Veikkola T, Djonov VG, Baeriswyl V, Schomber T, et al. (2007) Distinct roles of vascular endothelial growth factor- $D$ in lymphangiogenesis and metastasis. Am J Pathol 170: 1348-1361.

14. Mylona E, Alexandrou P, Mpakali A, Giannopoulou I, Liapis G, et al. (2007) Clinicopathological and prognostic significance of vascular endothelial growth factors (VEGF)-C and -D and VEGF receptor 3 in invasive breast carcinoma. Eur J Surg Oncol 33: 294-300.

15. Nakamura Y, Yasuoka H, Tsujimoto M, Imabun S, Nakahara M, et al. (2005) Lymph vessel density correlates with nodal status, VEGF-C expression, and prognosis in breast cancer. Breast Cancer Res Treat 91: 125-132.

16. Nakamura Y, Yasuoka H, Tsujimoto M, Yang Q, Imabun S, et al. (2003) Prognostic significance of vascular endothelial growth factor $D$ in breas carcinoma with long-term follow-up. Clin Cancer Res 9: 716-721.

17. Zhao YC, NiXJ, LiY, Dai M, Yuan ZX, etal. (2012) Peritumoral lymphangiogenesis induced by vascular endothelial growth factor $C$ and $D$ promotes lymph node metastasis in breast cancer patients. World J Surg Oncol 10: 165.
18. Shibata MA, Morimoto J, Shibata E, Otsuki Y (2008) Combination therapy with short interfering RNA vectors against VEGF-C and VEGF-A suppresses lymph node and lung metastasis in a mouse immunocompetent mammary cancer model. Cancer Gene Ther 15: 776-786.

19. Shibata MA, Shibata E, Morimoto J, Harada-Shiba M (2013) Therapy with siRNA for Vegf-c but Not for Vegf-d Suppresses Wide-spectrum Organ Metastasis in an Immunocompetent Xenograft Model of Metastatic Mammary Cancer. Anticancer Res 33: 4237-4247.

20. Shibata MA, Ambati J, Shibata E, Albuquerque RJ, Morimoto J, et al. (2010) The endogenous soluble VEGF receptor-2 isoform suppresses lymph node metastasis in a mouse immunocompetent mammary cancer model. BMC Med 8: 69.

21. Currie MJ, Hanrahan V, Gunningham SP, Morrin HR, Frampton C, et al. (2004) Expression of vascular endothelial growth factor $D$ is associated with hypoxia inducible factor (HIF-1alpha) and the HIF-1alpha target gene DEC1, but not lymph node metastasis in primary human breast carcinomas. J Clin Pathol 57 829-834.

22. Mohammed RA, Green A, El-Shikh S, Paish EC, Ellis IO, et al. (2007) Prognostic significance of vascular endothelial cell growth factors $-A,-C$ and -D in breast cancer and their relationship with angio- and lymphangiogenesis. $\mathrm{Br} J$ Cancer 96: 1092-1100.

23. Zhao YC, Ni XJ, Wang MH, Zha XM, Zhao Y, et al. (2012) Tumor-derived VEGF-C, but not VEGF-D, promotes sentinel lymph node lymphangiogenesis prior to metastasis in breast cancer patients. Med Oncol 29: 2594-2600.

24. Albuquerque RJ, Hayashi T, Cho WG, Kleinman ME, Dridi S, et al. (2009) Alternatively spliced vascular endothelial growth factor receptor-2 is an essential endogenous inhibitor of lymphatic vessel growth. Nat Med 15: 10231030

25. Shibata MA linuma M, Morimoto J, Kurose $H$, Akamatsu $K$, et al. (2011) alpha-Mangostin extracted from the pericarp of the mangosteen (Garcinia mangostana Linn) reduces tumor growth and lymph node metastasis in an immunocompetent xenograft model of metastatic mammary cancer carrying a p53 mutation. BMC Med 9: 69 .

26. Shibata M, Matoba $Y$, Tosa $H$, linuma M (2013) Effects of mangosteen pericarp extracts against mammary cancer. Altern Integ Med 2: 8 . 